UDK 78.082.1 Grieg

Kjell Skyllstad

Institutt for musikk og teater, Universitetet i Oslo

Inštitut za glasbo in gledališče Univerze v Oslu

\title{
Nordic Symphony - Grieg at the cross-roads
}

\section{Nordijska simfonija - Grieg na razpotju}

Ključne besede: Edvard Grieg, nacionalno v glasbi, nordijska glasba

\section{POVZETEK}

V glasbenem zgodovinopisju se pojem Evrope pojavlja $\mathrm{z}$ razmejitvijo na osrednjo, "univerzalno" glasbeno kulturo in periferne, "nacionalne" usmeritve. Skladatelji 19. stoletja iz Skandinavije in Vzhodne Evrope si delijo usodo marginaliziranih ustvarjalcev, provincialnih predstavnikov "nacionalnih" ali "regionalnih" kultur in so postavljeni nasproti tistim, ki "govorijo jezik človeštva" (Alfred Einstein). V Nemčiji je Edvard Grieg še vedno "Kleinkünstler" in naj ne bi bil sposoben ustvarjati obsežnih sonatno zasnovanih glasbenih del, ki bi ustrezala merilom "univerzalne" umetnosti. Kar danes prepoznavamo kot norveško ali nacionalno v Griegovih delih, se je izoblikovalo kot nosilec tovrstne pomenskosti in interpretacij šele po skladateljevi smrti. Hermenevtična deskriptivna analiza ter kritika v Nemčiji (Hermann Kretzshmar) in na Norveškem (Gerhard Schjelderup) je zožila interpretacijo njegovih del. To je bil nadaljnji ideološki vložek s strani vzburkane norveške nacionalistične glasbene kulture ob koncu 1920. Ko so Griegovo Simfonijo prvič izvedli leta 1981, so jo slogovno označili za prehod k "pravemu" Griegu, svoje stališče pa so utemeljevali s posameznimi potezami glasbenega stavka, ki jih je mogoče navezati na nacionalni idiom. Avtor članka zagovarja bolj odprto držo pri obravnavi kompleksne narave Griegove kompozicijske kariere. Analiza njegovih večjih del, vključno s Simfonijo, brez
Keywords: Edvard Grieg, Nationalism in music, Nordic music

\section{SUMMARY}

In music historiography there appears the notion of a Europe musically divided between a central "universal" culture and a peripheral "national " orientation. 19th century composers of the Scandinavian and East European countries share the same fate of being marginalized as provincial representatives of "national" or "regional" cultures, in contrast to those that "spoke the language of humanity" (Alfred Einstein). In Germany Edvard Grieg is still derogatively regarded as Kleinkünstler, who was not able to produce large scale works in sonata form, which alone would qualify for the stature of a "universal" artist. What we now recognize as Norwegian or national in Grieg's works became carriers of such significance and interpretations only after the composer's death. The hermeneutic descriptive analysis and criticism in Germany (Hermann Kretzshmar) and Norway (Gerhard Schjelderup) narrowed the interpretation of his works. This was further ideologically encased by the upsurge of Norwegian nationalistic music culture in the late 20ties. When Grieg's only symphony was released for performance in 1981 it was stylistically considered as a transition to the "real" Grieg with reference to the elements pointing to a national idiom. The author pleads for a more open attitude in approaching the complex nature of Grieg's compositional career. Unbiased analyses of his large scale works, includ- 
omenjenih predsodkov priča o izostrenem čutu za oblikovno strukturiranje, tudi pri odstopanju od normativnih zahtev glasbenih zvrsti. Umetniško zapuščino Edvarda Griega, kot mnogih drugih skladateljev "perifernih" kultur, je treba obravnavati torej znotraj trojnega križišča, kjer se srečujejo nacionalno, regionalno in evropsko ter v polju slogovnih trendov, sociokulturnega ozadja in razvoja glasbene komunikacije. ing the symphony, testify to an acute sense of formal structure, even when deviating from the normative requirements of the genre. The artistic legacy of Edvard Grieg, like that of many other composers of "peripheral" cultures, need to be examined at the triadic point of dynamic convergence between the national, regional and European, and between stylistic trends, socio-cultural background and the development of musical communication.

One of the most important insights gained through the international musicological cooperation of recent years is the clear understanding of the crosscultural dimensions in the development of music. Music history, intimately tied up with the intercultural processes, provides an excellent field for the study of cultural interaction. The upsurge in nationalism and belief in "pure" cultures that haunts many nations today makes it paramount for musical research to give high priority to further research into the uniting and binding aspects of European music. If stress on exclusiveness and individuality was necessary to foster national identity, time has now come to point to our common heritage to pave the way to cooperation and integration.

The symphonic legacy of Edvard Grieg requires, it seems to me, to be examined in the point of convergeance between three cultural streams- the European, the Nordic and our own musical heritage, and in the triadic point of interaction between stylistic trends, the socio-cultural background and the development of musical communication.

The dilemma of many music historians in treating the romantic movement is the reluctancy to see Europen music culture as a whole. There is in their minds a central continental development and there is a periphery, there are the major works and the minor, there is innovation and adaptation. In his standard work "Music in the Romantic Area", Alfred Einstein clearly demonstrates this predicament. After having treated the musical history of Central Europe according to genres, a few pages are then left to the description of the peripheric national cultures, the "border" nations under the heading Nationalism. The contributions of these nations, according to Einstein, in the final end led to a regionalization of music. And he goes on to say: "This was the complete antithesis to the Classic trend, whose great glory had been that it stood above the nations, that it spoke the language of humanity ..." ${ }^{1}$

The idea of the cultural backwardness of these nations is illustrated in his treatment of Russian music through a rather biased metaphor:

"The situation is somewhat like that of a savage people which comes into contact with European civilization and suddenly is placed in the position of using the achievements of a civilization it has not created ...." Norway is arraigned with these cul-

\footnotetext{
1 Alfred Einstein: Music in the Romantic Era, London 1947, p. 333.

2 Ibid., p. 302.
} 
tural latecomers: "Last of all, Norway took its place among the musical nations of the Scandinavian peninsula." ${ }^{3}$

Although later modifying his one-sided view of Nordic music, he initially dismisses it as provincial: "There was, moreover, no outstanding personality who with his music re-influenced Europe, as did, in literature, the Danes Kierkegaard and J. P. Jacobsen, the Norwegian Henrik Ibsen, or the Swede August Strindberg. National coloring was often so weak that it merely suggested a region and should be thought of simply as native rather than national art." ${ }^{4}$

The difficulty with Einsteins point of view is the lack of a more inclusive analysis that includes the cultural debate of the times. In Germany Beethoven in no way was considered to be "above the national" but functioned within a national framework as much as any of the romantic composers of the times. On the other hand one could with great conviction maintain that the exponents of national romantic music upheld the transnational lofty ideals of freedom just as much as the classics.

In fact one finds a reciprocal fertilization. Not at least within the symphonic genre.

The Danish musicologist Niels Martin Jensen points to "the almost trailblazing significance for the european symphonic genre" of Gade's first symphony "not least through its unconditional acceptance in Leipzig“. He cites Hermann Kretzchmar (1913): "The c-minor Symphony gave the higher instrumental music impulses of the greatest importance." ${ }^{5}$

Among composers in Leipzig, Nordic music became a center of attraction. In fact what one could rightly term a Nordic musical dialect evolved from compositional experiences shared by Nordic and German composers alike. And this milieu knew no distinction or discrapncy between a music communicating the noblest of universal values and a nationally oriented creativity, as Einstein suggests. I have in a former article pointed to the openness of the musical aesthetics of Moritz Hauptmann, Griegs teacher at the Leipzig Conservatory. ${ }^{6}$ And Schumann's admonition to Gade that universality can only be attained through the national seems to sum up the spirit of Leipzig.

The meeting with Danish nationalism by artists from other Scandinavian countries was indeed in every way an encounter with common Nordic roots. This also explains the influence Gade and Hartmann initially could wield on Grieg.

It should be remembered that the first documents of Danish national romanticism had their origin outside of Denmark, like Oehlenschlägers plays Håkon Jarl (1805) and Palnatoke (1807) and the first Danish national romantic painting "Ymir dier koen $\varnothing$ dhumbla" (N. A. Abildgaard 1777). Decisive works for the creation of a national emotional involvement were Oehlenschlagers "Nordiske Digte" (1807) and Grundvigs "Nordens mytologi" which mirrors his search for a living folk culture.

3 Ibid., p. 320.

4 Ibid., p. 317.

5 Niels Martin Jensen "Dansk nationalmusik. Forsög til en begrebs- og indholds bestemmelse" in Musik og forskning, København 1987/8 årg. 3, p. 42.

6 Kjell Skyllstad: "Theories of musical form as taught at the Leipzig Conservatory, in relation to the musical training of Edvard Grieg، in Studia Musicologica Norvegica, Oslo, b. 1 1968, pp. 69-78. 
Toward the middle of the century the cult of the Nordic past gripped the student movement. In 1845 "Nordic Christmas" was celebrated in the Copenhagen Student Association by Swedish, Danish and Norwegian students, gathered "to empty the Bragiscup for remembrance of the past and the cup of promise for the hope of the future." "The walls were covered with full-size paintings of the gods of Walhalla. painted by nationally oriented artists like L. Frölich, also renowned for his 30 illustrations of Danish antiquity made for Fabricius' "Illustreret Danmarkshistorie for Folket", and Oehlenschlägers' "Nordens Guder".

Folk ballads and Oehlenschläger, sagas and mythology, nordic antiquity and middle ages - all filtered through romantic phantacy and transformed into vivid sound pictures and tone poems, this was the music of Danish national romanticism, first and foremost represented by I. P. E. Hartmann (1809-1900) and N. W. Gade (1817-1890). The first flowering came in the fourties with works like Gades "Nachklänge von Ossian" (1841), the c-minor symphony (1842) and Hartmann's ouverture to Haakon Jarl (1844). In 1843 the Gade symphony was introduced with great success in Leipzig by Mendelssohn. Niels Martin Jensen quotes a contemporary testimony, the preface to Berggreen's Folkesanger og Melodier, as an example of the reception of this work as both artistic and social avantgarde. ${ }^{7}$

The national romantic movement however, seems gradually to have lost its momentum, so much so that Hartmann in 1865 consider it the task of the artist to keep the national fires burning:

"I think, that the more the national becomes underbalanced in real life, the more it becomes the duty of the artist to uphold it in the world of ideas." ${ }^{8}$

National romanticism in Danish music up to the war of 1864 seems to lose its function as political avantgarde which is also mirrored in its increasingly epigonal stylistic character. Already in 1846 a more subdued tone can be observed in Hartmanns "Liden Kirsten", so that the national romantic movement more or less was split in two - one radical and the other conservative.

Griegs symphony, which he finishes in 1864 thus comes at a decisive turning point. In a sense commissioned by Gade, the symphony seems to have presented no unsurmountable task to Grieg, which is clearly demonstrated by the fact that the first movement was composed and fully orchestrated within two weeks. This is amazing in view of the fact that aside from Winther Hjelm there had been no other Norwegian attempts in the genre. It is not surprising then that Grieg at the outset of his career did not have any qualms about demonstrating his attachment not only to the German symphonic tradition which he knew so well, but especially to the main works of the Danish romantic symphonic repertory.

It is a known fact that Grieg during his later life looked back to his Leipzig period with mixed feelings, and that he considered the symphony as an example of a stylistic dependancy on the Schumann-Mendelssohn tradition that he soon was to liberate himself from. Grieg however did not at that time choose an easy way out. If he

7 Niels Martin Jensen: Op.cit., pp. 38, 39.

8 Ibid., pp. 48, 49. 
would have wanted the approval of the general concertgoing public, he could have chosen an easier road. If we negatively judge the traditional models he tries to bring together in his symphony, we must remember the general attitudes of the public. We know that even in Leipzig Schumann was sometimes considered too advanced for the general taste. In the Copenhagener "Tidsskrift for Musik" from 1859 there is even a complaint against a performance of Schuberts C-major symphony. ${ }^{9}$

It would be only be natural to compare the overall compositional construction of Griegs symphony with the Beethovian dramaturgy of Gades first symphony - the struggle from darkness to light which no doubt is interpreted within a progressive ideological framework. Jens Martin Jensen comments on Gades position in the forties: "For Gade ... the lines between artistic liberation and social democratization at that time - partly in contrast to his later stand ... were not sharp. " ${ }^{10}$

The position of the Vienna classics in Leipzig of the fifties, which must have made a deep inprint on Grieg is forcibly expounded by Ferdinand Brendel, Professor at the Conservatory in his music history "Geschichte der Musik in Italien, Deutschland and Frankreich" (Leipzig 1852) While Italian music has degenerated into sensuality, the music of Germany, he holds, has experienced a new great upsurge which opens up new perspectives for the music of the future. ${ }^{11}$

While he sees Mozart as the genius that gave German music universal appeal, Beethovens music means the return to the patriotic on a higher level. "The former universal height has been left behind, and a new peak has been conquered through the deeper commitment to the national." ${ }^{12}$

Beethoven is called "Composer of the new spirit evoked by the Revolution" and "Composer of the new ideas of freedom and equality, emancipation of peoples, classes and individuals. ${ }^{13}$

No doubt these ideas found fertile soil in the mind of young Grieg. There is however another side to the story. While Brendel in his Beethoven interpretation sides with the progressive national and liberal ideology of his times, already this German nationalism is beginning to take on chauvinistic overtones when he declares "the historic task of Germany to have been the gathering of all the other peoples' spirits around the throne of its universal monarchy ${ }^{14}{ }^{14}$

The ideological invasion of Beethoven in Germany so conspicuously ushered in by Wagners nationalistic interpretation of his heroism, and reaching a momentary culmination in the times of the German-French war could not have failed to draw Grieg's attention. There could be reason for caution in leaning back on a classically oriented heroic vocabulary that was so conspiculously being taken over for ideologi-

\footnotetext{
${ }^{9}$ Musikforeningens Festskrift 5 Marts 1886 b.II, København 1886 pp. 137,138.

${ }^{10}$ Niels Martin Jensen: Op. cit., p. 42.

${ }^{11}$ Franz Brendel: Geschichte der Musik in Italien, Deutschland and Frankreich, Leipzig 1852. New ed. 1903, p. 133 cited in Erich Reimer: "National Consciousness and Music Historiography in Germany 1800-1850" History of European Ideas vol. 16 Number 4-6 Oxford 1993, pp. 721-727.

${ }^{12}$ Ibid., p. 313.

${ }^{13}$ Ibid., p. 324

${ }^{14}$ Ibid., p. 134.
} 
cal reasons. Griegs youthful tribute to Beethoven in his Symphony is not yet shadowed by this development. However there is reason to believe that his difficulties in completing Olav Tryggvason could also have its root in increasing doubts about the kind of message conveyed by the heroic idiom.

In a previous article I have pointed out the stylistic and structural similarities of the Symphony with the musical language especially of Hartmann, with his angular, forceful symphonic gestures. ${ }^{15}$ There is in contrast to this all the smoothly flowing lyricism of Schumann with mild elegiac undertones and the more elegant but often sprightly youthful orchestral landscapes of Mendelssohn, with characteristic woodwind colours. One may easily point to elements of formal inbalance in the work. And yet when listening the music in a very special way holds together. Is it only a result of instinct, a fortunate stroke of imagination?

I do not think so. The real character of the Symphony it seems to me lies in the way these elements are used to create a dramatic whole. Grieg here is definitely not the Kleinkünstler who throws together odds and ends from the symphonic repository without a dramaturgic conception of a coherent whole. On the contrary the symphony contains all the vital elements of his personal modes of expression. First of all one would point to the concentrated energetic first theme of a classical mold, the sheer energy of which motors the subsequent melodious outpouring creating a symphonic space. Thus the classical and romantic heritage function within a unitary structural concept. This concept is in the symphony as in the later Piano Concerto principally based on the antithetic thematic dynamism, and functions within the barform principle. Remarkable parallelisms between the thematic constructs of the two works reveal the continuity in Grieg's handling of larger forms.

Such a tight structural conception of the first movement allows for a great degree of playfulness in motivic work out and freedom in handling the slow movement and the scherzo. The last movement is then conceived both in the Symphony and the Piano Concerto as a final rhythmic release of bent up forces.

Grieg wrote only one Symphony and one Piano Sonata. It seems that when he gave up a style, he gave up the genre as well. They were one of a kind, documents from a period that was to pass, one of unspoiled youthful enthousiasm and energy. His artistic development was to lead in the direction of seeking a national stylistic foundation. By some this is extolled as the "real " Grieg. The "preparatory" nordic style period then would aquire musical value in the degree to which it displays leads to this development. As is often the case music production is judged in an evolutionary context, leading to or from something.

The noted music sociologist Dag Østerberg has a similar directional conception of music history but with the opposite conclusion when it comes to Grieg's stylistic development. In an article published shortly after the new premiere of the Symphony in 1981 he contends that the national orientation in Grieg's music became something like a straightjacket, leading him into a romantic mediocrity where he

${ }^{15}$ Kjell Skyllstad: „Thematic Structure in Relation to Form in Edvard Grieg's Cyclic Works. The Nordic Tradition" in Studia Musicologica Norvegica b. 6 Oslo 1980 pp. 97-126. 
discards the seeking for "true" form and only mirrors the romantic-idealistic world of a pre-capitalistic era. He sees the a-minor concerto as such an ideological work with its evocation of harmonious nature and folklore, thus avoiding the social reality of the looming industrial age. Grieg in his eyes thus in his giving in to a nationalist ideology becomes a "grand destin manque " ${ }^{16}$

In apparent opposition to this the works of the youthful Grieg, and particularily the Symphony are judged according to a concept of Grieg as a national composer. There is no doubt that what we now recognize as Norwegian or national in Grieg, became carriers of such significations and interpretations only after Grieg's death. An important contribution to this was the dominance of a hermeneutic descriptive analysis and critizism both in Germany (Kretschmar) and Norway (Schjelderup) that ideologically closed and narrowed the interpretation of Grieg. This was further encased by the nationalistic music culture of the late twenties and beginning thirties, the importance of emphasizing national symbols during the war years and the post-war presentations in the media, like the "Song of Norway".

The reception of the Symphony in 1981 gives evidence of the strength of this identification. After the "premiere in Bergen, our daily papers had this to say: "As a whole the work to-day seems somewhat pale and uneven, and hardly gives us a glimpse of the style that we consider characteristic of Grieg. " ${ }^{17}$ "On the other side there were passages one has always attributed to Grieg. Melodic turns, rhythmic combinations and a sense of color and instrumentation that bore the unequivocal stamp of the originator." ${ }^{18}$

"In spite of the first movement being the most cosmopolitan, I find a unmistakingly Norwegian and 'Griegian' tone ... The third movement with its sprightly rhythmic boyancy anticipates the later Grieg." ${ }^{19}$

"The third movement anticipates the later Grieg as we know him in the Piano Concerto. A sprightly springar theme and a more subdued theme that bear the national stamp that made Grieg world famous. ${ }^{20}$

"As already mentioned, Grieg's true characteristics only occasional come to the front, as in the sprightly Scherzo and especially in the opening of the Finale.." ${ }^{21}$

"Sporadically we are surprized by Griegean turns and melodic formulas. After the second theme in the first movement the music sounds unmistakenly Grieg, and the final movement gives us a hint of a coming master." ${ }^{22}$

"But even in the c-minor symphony Grieg does not hide himself. Even if one finds it easy to pinpoint external influences, it would be just as easy to find Norwegian characteristics in the symphony. This especially applies to melodic elements. In the first allegro movement one finds turns that he was later to use among other places in

\footnotetext{
${ }^{16}$ Dag Østerberg: "Grieg, hans musikk og den romantiske filosofi" i Basar, Oslo 4/81, p. 123.

17 Adresseavisen 23. May 1981.

${ }^{18}$ Aftenposten 1. June 1981.

${ }^{19}$ Verdens Gang 1. June 1981.

${ }^{20}$ Gjengangeren 1. June 1981.

${ }^{21}$ Morgenbladet 1. June 1981.

${ }^{22}$ Morgenavisen 1. June 1981.
} 
one of the violon sonatas, and in the lyrical trio of the third movement one immediately recognizes the folk tune 'Astri mi Astri', to give some examples."

The symphony thus is considered from two points of view: Either as a transition to the "real" Grieg, the national hero who created the "golden age" of Norwegian music, or a transition away from the "real" Grieg with a commitment to artistic truth and an international orientation. The signature "Must not be performed" indicates could accordingly be interpreted either as a discreditation of a work not considered fit as a Norwegian symphony (in contrast to Svendsen) a carrier of national spirit, or as an attempt to forget and hide away "what could have been" in a European context. Both are in my opinion constructs.

Works are artistic manifestations relating to and reacting to the concrete reality in all its multifacetted compleksity. With his acute sensibility, composite character and early life experiences Grieg responded to the whole of this pressing reality. His national commitment cannot be denied, but in no way should be discredited as romantic idealism that prevented him from becoming a true world citizen. Of course the tension between the national and the international was always present and had to be if Grieg's music in any way could be said to mirror the Norwegian character. A work like the g-minor Ballad is a good example of the strength of this dynamism. The postcard idyll that $\varnothing$ sterberg equivates with his national style is likewise an interpretive construct. How can anyone postulate that the romantic expression of longing for nature does not imply the industrial urban development and the growing estrangement of human relations. Could it not be more natural to interpret works like the Ballade or the g-minor Quartet as musical mirrors of this estrangement, the growing gap between man and society and man and nature. At any rate these works have very little to do with romantic idylls.

Discreditation of works by the author is no rarity in artistic history. Rather they testify to the character that Østerberg misses in Grieg: artistic integrity. As pointed out before, the ideological place of the heroic presented increasing problems of identification. This is most clearly seen in the failure of the Olav Tryggvason project and the turning in Peer Gynt to the grotesque means to discredit national selfsufficiency. A Europe tormented by the nationalist scourge would today have needed a Grieg to refind its balance. 